\title{
Human Catalase Polymorphisms in Egyptian Patients with Chronic Hepatitis C Virus
}

\section{Lamyaa Fahmy $^{1}$, Ibrahim Helmy ${ }^{2}$, Roba Talaat ${ }^{1}$, Khaled Bassiouny $^{1}$, Gamal Badra $^{3}$}

1 Molecular Biology Department, Genetic Engineering and BiotechnologyResearch Institute (GEBRI), Universityof Sadat City, Egypt. ${ }^{2}$ Biochemistry Department, Faculty of Science, Kafr El-SheikhUniversity, Egypt.

${ }^{3}$ Internal Medicine Department, National Liver Institute, MenoufiaUniversity, Egypt.

\begin{tabular}{l}
\hline A R T I C L E I N F O \\
\hline HCV, HCC, CAT, SNP, \\
Polymorphism
\end{tabular}

Polymorphism

\begin{abstract}
A B S T R A C T
Background: Catalase (CAT), one antioxidant enzyme, may provide resistance against many diseases. Many previous studies reported predictive and prognostic values of CAT C262T polymorphism in cancers, with divergent results. The present study was planned to assess the presence of CAT C262T polymorphisms in Egyptian patients with chronic hepatitis C virus .Methods: Genomic DNA from peripheral whole blood of 243 patients with chronic hepatitis C, of whom134 patients had hepatocellular carcinoma (HCC) and 112 healthy controls were extracted and amplified .The detection of the genetic polymorphisms of CAT C262T were determined by single nucleotide polymorphisms (SNPs) using polymerase chain reaction-restriction fragment length polymorphism (PCR-RFLP).Results: The obtained results showed that, $\mathrm{CC}$ genotype in controls was higher than patients (HCV, HCC) in contrary with TT genotype. The results indicated that the distribution of the CC, TT genotypes were significantly different between the control and HCV group (P $=0.003,0.005$ respectively), the similar results showed with HCC group in compared with control $(\mathrm{P}=0.006,0.008$ respectively). On the other hand, the CT genotype showed no significantly different between the control and the patients of HCV, HCC groups $(\mathrm{P}=0.272,0.292$ respectively.

Conclusion: The CAT C262T polymorphisms may be play a role in the etiology of hepatocellular carcinoma but further studies are necessary to confirm our data.
\end{abstract}

(C) 2018Publisher All rights reserved.

\section{INTRODUCTION}

Oxygen is an element indispensable for life ${ }^{(1)}$. When cells use oxygen to generate energy, free radicals are created as a consequence of ATP (adenosine triphosphate) production by the mitochondria. These by-products are generally reactive oxygen species (ROS). At low or moderate levels, ROS exert beneficial effects on cellular responses and immune function; whereas at high concentrations, they generate oxidative stress, a deleterious process, that can damage all cell structures $^{(2)}$, and can damage nucleic acids and proteins, thereby altering their functions. The human body has several mechanisms to counteract 
oxidative stress by producing antioxidants. A shift in the balance between oxidants and antioxidants in favor of oxidants is termed as "oxidative stress". Under normal conditions, living organisms maintain a steady-state balance between the production of reactive oxygen metabolites (.OH, O2.- and $\mathrm{H} 2 \mathrm{O} 2$ ) and their destruction by antioxidant molecules (e.g.,ascorbic acid, glutathione, a-tocopherol), as well asby antioxidant enzymes ${ }^{(3)}$. Catalase (CAT) is one of the antioxidative endogenous enzymes.This enzyme, acting in cooperation with other ones, plays an important role in protecting cells against the toxic effects of hydrogen peroxide. In human,it has been implicated indifferent physiologica land pathological conditions.CAT is an enzyme containing heme in its structure. Its role is to control the cellular levels of $\mathrm{H} 2 \mathrm{O} 2$ by its decomposition to water $(\mathrm{H} 2 \mathrm{O})$ and oxygen (O2) (4) particularly under oxidative stress conditions ${ }^{(5)}$. CAT is a homotetramer of $220-230 \mathrm{kDa}$ mass, encoded by agene consisting of 13 exons separated from each other by 12 introns. The gene is localized on chromosome $11^{(6)}$.Genetic changes involving antioxidative enzymes can be responsible for changes of their activity and expression. A few polymorphisms have been described for the catalaseencoding gene. Point mutation involving guanine substitution by adenine in intron 4 is a cause of splicing abnormality (7) whereas thymine deletion in exon 4 causes a catalasemia ${ }^{(1)}$ Polymorphism $844 \mathrm{G}>\mathrm{A}$ is associated with development of hypertension ${ }^{(9,10)}$ One of known polymorphisms is substitution of cytosine with thymine in nucleotide $262(-262 \mathrm{C}>\mathrm{T})$. The presence of such polymorphism affects transcriptional factor ${ }^{(11)}$. Substitution of thymine for cytosine in nucleotide 262 generates three genotypes: CC ,TT and CT genotypes. In comparison with the variant $C$ allele, the variant $T$ allele of the CAT C262T polymorphism has been reported to indicate lower enzyme activity, thus raising the levels of ROS and might lead to cancer development or progression ${ }^{(12)}$.Recently, a series of studies has demonstrated the associations between the CAT C262T polymorphism and risk for multiple cancers, such as breast cancer (13), prostate cancer $^{(14)}$, hepatocellular ${ }^{(15,16)}$. The purpose of the present study was to evaluate the presence of CATC262T polymorphism in Egyptian patients with chronic hepatitis $\mathrm{C}$ virus.

\section{Patients and methods}

\subsection{Study population}

The current study was carried out on 243 diagnosed Egyptian patients with chronic hepatitis $\mathrm{C}$ virus. Their ages ranged from 38 to 73 years. Patients were recruited from NLI (National Liver institute); Menoufia University; Egypt. One hundred and twelve healthy subjects were included in the study as control group. The patients were selected during period 2014 to2016.All of patients were have positive of serum hepatitis $\mathrm{C}$ virus identified by serology and confirmed by qualitative PCR to detect HCV-RNA .The HCC patients had focal lesion that were detected by ultra-sonography and computed tomography (CT)scan .Blood samples were obtained only from patients who gave informed consent .A full history was taken for all patients and control .Peripheral blood samples were collected in two tubes, the $1^{\text {st }}$ for routine workup and another one for DNA 
extraction.All investigations were performed in accordance with the Menoufia University, Health and Human Ethical Clearance Committee guidelines for Clinical Researches.

\subsection{Genotyping of CAT gene}

Genomic DNA was extracted from whole blood using QIAamp DNA Blood Mini kit (Qiagen, USA)following the manufacturer's instruction. The extracted DNA was stored at $-20^{\circ} \mathrm{C}$ until analyzed. Genotyping of the gene was performed by polymerase chain reactionrestriction fragment length polymorphism (PCR-RFLP) method. Reagents and primers were provided by Qiagen, USA.DNA encoding the promoter region of the CAT gene containing a -262 C-T substitution was amplified by(PCR). The total volume for each PCR reaction was $12.5 \mu \mathrm{l}$; PCR reaction ingredients were Dream TaqGreen Master Mix 2x (Fermentas, Thermo Fisher Scientific Inc.), 10 pmoles of each CAT primers $\mathrm{F}$ : 5'AATCAGAAGGCAGTCCTCCC3'. andR5':TCGGGGAGCACAGAGTGT AC3'and $0.1 \mu \mathrm{g}$ DNA. After a $3 \mathrm{~min}$ denaturing step ,amplification was performed according to the following cycling profile: $94{ }^{\circ} \mathrm{C}$ for $30 \mathrm{sec}, 63{ }^{\circ} \mathrm{C}$ for $30 \mathrm{sec}$ and $72{ }^{\circ} \mathrm{C}$ for $30 \mathrm{sec}$ (35cycles). The final elongation step was 5 minat $72{ }^{\circ} \mathrm{C}$. Amplification product 250 bp(fig.2) was digested with restriction enzyme HinfI. The restricted PCR products were electrophoresed through $3 \%$ ethidium bromide stained agarose gel, and visualized by ultraviolet light.The 262T allele produced an undigested product of $250 \mathrm{bp},-262 \mathrm{C}$ allele two products: $177 \mathrm{bp}$ and $77 \mathrm{bp}$.(fig 3) For quality control, genotyping of $10 \%$ of the samples was repeated. Samples were randomly chosen and interpreted blindly by two different observers. The results obtained were identical to the initial results.

\subsection{Detection of HCV RNA}

Patients and controls' sera were tested for HCV RNA using RT-PCR method.

\section{Statistical analysis}

Data were analyzed with statistical Package for the Social Sciences(SPSS version 20.0).According to the type of data qualitative represent as number and percentage, quantitative continues group represent by mean $\pm \mathrm{SD}$, the following tests were used to test differences for significance; Differences between frequencies (qualitative variables)and percentages in groups were compared by Chisquare test. Differences between parametric quatitative independent multiple groups by ANOVA.

\section{Results}

The biochemical characteristics of the patients are described in Table 1. Patients were grouped into two groups ; patients with chronic $\mathrm{HCV}$ and a subgroup diagnosed with HCC, in addition the control group consisted of 112 subjects. Regarding the biochemical data, the haemoglobin, platelets count ,AST, ALT, Albumin , the total bilirubin, creatinin and alphfetoprotein levels were significantly differences .On the other hand, TLC showed no difference between patients and control.

The allele and genotype frequencies for the CAT-262C/T single nucleotide polymorphisms (SNP) in control and patients are shown in Table 
1\&2. In the HCV group, the $\mathrm{T}$ allele was significantly over-represented compared with control cohort: of 486 HCV alleles, 211(43\%) had the T allele compared to 66/224 (29\%) control alleles $(\mathrm{P}=0.001)$, also, HCC patients gave the same results when compared with control: of $286 \mathrm{HCC}$ allele , $118(44 \%)$ had the $\mathrm{T}$ allele $(\mathrm{P}=$ 0.001).The results also indicated that the distribution of the $\mathrm{CC}, \mathrm{TT}$ genotypes were significantly different between the control and HCV group ( $P$ $=0.003,0.005$ respectively), the similar results showed with $\mathrm{HCC}$ group in compared with control ( $\mathrm{P}=0.006,0.008$ respectively). On the other hand, the $\mathrm{CT}$ genotype showed no significantly different between the control and the patients of $\mathrm{HCV}, \mathrm{HCC}$ groups $(\mathrm{P}=0.272,0.292$ respectively).

When evaluating the distribution of combined genotypes $\mathrm{CC}+\mathrm{CT}$ and $\mathrm{CT}+\mathrm{TT}$ in the CAT gene in two groups(HCV patients and control),we found a highly significant $(\mathrm{P}=$ $0.004,0.003$ respectively) Table 2 .

Regarding to combined genotypes $\mathrm{CC}+\mathrm{CT}$ and $\mathrm{CT}+\mathrm{TT}$ in HCC group, also it was found a significant differences compared with control ( $p=0.008,0.006$ respectively)Table 3 .

Fig 1.Showed the percent of CAT262CT genotypes in different groups. We found that the percent of genotype $\mathrm{CC}$ in control samples was high incidence $(51.8 \%$ )in comparison with two groups of patients $(\mathrm{HCV}=35.8$ $\%, \mathrm{HCC}=35.1 \%)$, in contrast the genotype $\mathrm{TT}$ in patients $(\mathrm{HCV}=22.6 \%$, $\mathrm{HCC}=23.1 \%$ ) was higher than in control samples(10.7\%).

\section{Discussion}

ROS are naturally generated from aerobic metabolism (17). The human body develops a sophisticated set of antioxidant molecules to prevent the toxic accumulation of these species ${ }^{(18)}$.CAT belongs to the antioxidant molecules and is present in all aerobic cells while the highest levels of the enzyme are found in the liver, kidney and erythrocytes ${ }^{(19)}$.CAT is a heme enzyme that plays a very important role in avoiding hydrogen peroxide concentration by converting hydrogen peroxide into water and oxygen, and protects cells from detrimental effects of oxidative stress ${ }^{(20)}$. Allelic variants of CAT gene may contribute to lower CAT enzymatic activity and higher sensitivity to ROS, and alter ROS detoxification and increase oxidative stress, thereby implicating oxidative DNA damage and modulating disease risk $^{(21)}$.Singlenucleotide polymorphisms (SNPs) are the most common type of genomic sequence variation and are thought to be associated with population diversity, susceptibility to disease, and individual response to drug treatment ${ }^{(22)} .245$ CAT SNPs have been identified, with most studies investigating the relationships between multiple diseases and a $\mathrm{C}>\mathrm{T}$ substitution at position -262 from the transcription start site ${ }^{(19)}$.Previous studies indicated that CAT C262T gene polymorphism had an influence on transcription factors binding thus altering the basal transcription and consequent expression of this enzyme and hence influenced the oxidative status of cells and its microenvironment ${ }^{(3)}$. Consequently, this polymorphism was believed to play a key role in the pathogens is of cancer (23). The growing studies investigated the relation of CAT C262T gene polymorphism to breast cancer, lung cancer, diabetic neuropathy, non- 
Hodgkin lymphoma, liver cancer and colorectal cancer ${ }^{(18,24)}$. Hepatocellular carcinoma (HCC) is a major source of cancer burden worldwide, and is the third leading cause of cancer related mortality ${ }^{(25)}$.Incidence varies widely between geographical areas, probably because of variations in the exposure to hepatitis virus and other environmental pathogens ${ }^{(26)}$. In Egypt, HCC is the second most common cancers in men and the $6^{\text {th }}$ most common cancers in women (GLOBOCAN 2008 database) (27). As with many cancers, variants of genes involved in multistage carcinogenesis may determine an individual's susceptibility to develop HCC. Our work was conducted to detect and evaluate the involvement of polymorphisms of the antioxidant enzyme CAT (C-262T) in genomic DNA from Egyptian patients with chronic hepatitis $\mathrm{C}$ virus, hepatocellular carcinoma (HCC) in comparison with DNA from healthy control. The obtained results inform about no significant correlation between genotype distribution and allele frequency both in the $\mathrm{HCV}$ patients and the patients with HCC. On the other hand, The present results showed that CAT TT genotype had statistically significant differences between patients and controls. This results are agreement with Ezzikouri et al.(2010) (28) who found that patients with the CAT TT genotype had more chance to have HCC caused by different etiologies when compared to a healthy control group .Also, Wang et al.(2015) ${ }^{(29)}$ found that the individuals who carry the TT homozygote have $17 \%$ increased risk of cancer compared with the $\mathrm{C}$ allele carriers, revealing that the CAT C262T gene polymorphism may be a risk factor for cancer. In contrast to our findings, Nahon et al.,(2009) ${ }^{(30)}$ previously showed that there is no association between $-262 \mathrm{C} / \mathrm{T}$ CAT polymorphism and hepatocellular carcinoma. To sum up, the results from the current study suggest that the CAT C262T polymorphism may contribute to genetic susceptibility to cancer, supporting the hypothesis that the polymorphism serves as a potential susceptibility tumor marker. Further well-designed, multicenter epidemiological studies are necessary to confirm our data in larger subjects and to evaluate the association between the CAT C262T polymorphism and cancer risk.

\section{REFERENCES}

1.Bucci E (2009).Thermodynamic approach to oxygen delivery in vivo by natural and artificial oxygen carriers. Biophys Chem, 142, 1-6.

3.Genestra M (2007).Oxyl radicals, redox-sensitive signalling cascades and antioxidants. Review. Cell Signal, 19, 1807-19.

3.Michiels C , Raes M,Toussaint $O$, Remacle J(1994).Importance of SEglutathione peroxidase, catalase, and CU/ZN-SOD for cell survival against oxidative stress.Free Rad. Biol. \&Med. 17 (3):235.

\footnotetext{
4.Valko M, Leibfritz D, Moncol J, Cronin MT, Mazur M, Telser J (2007).Free radicals and antioxidants in normal physiological functions and human disease. Int $\mathbf{J}$ Biochem Cell Biol. 39: 44-84.
} 
5.Kinnula VL, Everitt JI, Mangum JB, Chang LY, Crapo JD (1992). Antioxidant defense mechanisms in cultured pleural mesothelial cells. Am J Respir Cell Mol Biol. 7: 95-103.

6.Quan, F., Korneluk, R. G., Tropak, M. B., Gravel, R. (1986).Isolation and characterization of human catalase gene. Nucleic Acids Res. 14, 53215335 .

7.Wen JK, Osumi T, Hashimoto T, Ogata M (1990). Molecular analysis of human acatalasemia. Identification of a splicing mutation J Mol Biol. 211: 383393.

\section{Hirono A, Sasaya-Hamada F, Kanno} H, Fujii H, Yoshida T, Miwa S(1995). A novel human catalase mutation $(358 \mathrm{~T}$ ->del) causing Japanese-type acatalasemia. Blood Cells Mol Dis. 21: 232-234.

9.Jiang Z, Akey JM, Shi J, Xiong M, Wang $Y$, Shen $Y$, et al (2001). A polymorphism in the promoter region of catalase is associated with blood pressure levels Hum Genet. 109: 9598.

10.Zhou XF, Cui J, DeStefano AL, Chazaro I, Farrer LA, Manolis AJ, et al. (2005). Polymorphisms in the promoter region of catalase gene and essential hypertension. Dis Markers. 21: 3-7.

11.Christiansen L, Petersen HC, Bathum L, Frederiksen H, McGue M, Christensen $\mathrm{K}$ (2004). The catalase $262 \mathrm{C} / \mathrm{T}$ promoter polymorphism and aging phenotypes. J Gerontol A Biol Sci Med Sci. 59: B886-889.

12.Ahn J, Nowell S, McCann SE, Yu J, Carter L, Lang NP, Kadlubar FF,
Ratnasinghe LD, Ambrosone CB.(2006) .Cancer Epidemiol Biomarkers Prev. Jun;15(6):1217-22.

13.Kakkoura, M. G , Demetriou, C.A., Loizidou,M.A., Loucaides,G., Neo phytou,I., Malas,S., Kyriacou K., Hadjisavvas ,A(2015).MnSOD and CAT polymorphisms modulate the effect of the Mediterranean diet on breast cancer risk among GreekCypriot women. Eur J Nutr, 015-09715.

14.Karunasighe, N, Han ,D.Y., Goudie M, Zhu S., Bishop K., Wang A., Duan H., Lange K., et al.(2012).Prostate disease risk factors among a New Zealand cohort. J Nutrigenet Nutrigenomics 5, 339-351.

15.Su S, He K, Li J, Wu J, Zhang M, Feng C, Xia X, Li B (2015). Genetic polymorphisms in antioxidant enzyme genes and susceptibility to hepatocellular carcinoma in Chinese population: a case-control study. Tumour Biol 36, 4627-4632.

16.Suhail M, Sohrab S S,Qureshi A,Tarique M,Abdel-Hafiz H,Al-Ghamdi K,Qadri I(2018). Association of $\mathrm{HCV}$ mutated proteins and host SNPs in the development of hepatocellular carcinoma. Infection, Genetics and Evolution.60:160-172.

17.Ziech D1, Franco R, Georgakilas AG, Georgakila S, Malamou-Mitsi V, Schoneveld O, Pappa A, Panayiotidis MI(2010). The role of reactive oxygen species and oxidative stress in environmental carcinogenesis and biomarker development. Chem Biol Interact 188, 334-339. 
18.Finkel $\mathbf{T}(\mathbf{2 0 0 3})$. Oxidant signals and oxidative stress. Cur Opin Cell Biol 15, 247-254 .

19.Crawford, A., Fassett RG, Geraghty DP, Kunde DA, Ball MJ, Robertson IK, Coombes JS. et al.(2012). Relationships between single nucleotide polymorphisms of antioxidant enzymes and disease. Gene 501, 89-103,2012.

20.Bauer, G(2012). Tumor cellprotective catalase as a novel target for rational therapeutic approaches based on specific intercellular ROS signaling. Anticancer Res 32, 2599-2624.

21.Forsberg, L., de Faire, U. \& Morgenstern, R(2001).Oxidative stress, humangenetic variation, and disease. Arch Biochem Biophys 389, 84-93 .

22.Shastry BS.(2002).SNP alleles in human disease and evolution. J Hum Genet , 47: 561-566.

23.Ding, G.,Liu F, Shen B, Feng C, Xu J.,JDing Q (2012). The association between polymorphisms in prooxidant or antioxidant enzymes (myeloperoxidase, SOD2, and CAT) and genes and prostate cancer risk in the Chinese population of Han nationality. Clin Genitourin Cancer 10, 251-255.

\section{Hernandez-Guerrero C, Parra- Carriedo A,Ruiz-de-Santiago D,Galicia-Castillo O,Buenrostro- jauregui M, Diaz-Gutierrez C (2018).Genetic polymorphisms of antioxidant enzymes CAT and SOD affect the outcome of clinical ,biochemical, and anthropometric variables in people with obesity under a dietary intervention.Gene\&Nutrition 13:1-10.}

25.Zhou L, Yang Y, Tian D, Wang Y(2013). Oxidative stressinduced 1, N6thenodeoxyadenosine adduct formation contributes to hepatocarcinogenesis. Oncol Rep , 29(3): 875-884.

26.El-Serag HB.(2001).Epidemiology of hepatocellular carcinoma. Clin Liver Dis , 5: 87-107.

\section{Kouyoumjian S P,Chemaitelly} H,Abu-Raddad (2018).Characterizing hepatitis $\mathrm{C}$ virus epidemiology in Egypt:systematic reviews, metaanalyses, and meta-regressions.

Scientific Reports 8:1661.

28.Ezzikouri S, El Feydi AE, Afifi R, Benazzouz M, Hassan M, Pineau P, Benjelloun S.(2010). Polymorphisms in antioxidant defense genes and susceptibility to hepatocellular carcinoma in a Moroccan population. Free Radic Res ,44(2): 208-216.

\section{Wang C.D,Sun,Y.,Chen N.,Huang} L.,Huang J-W,Zhu M.,Wang T,Ji YL(2015). The role of catalase $\mathrm{C} 262 \mathrm{~T}$ gene polymorphism in the susceptibility and survival of cancers. Scientific Reports 6:26973.

30.Nahon P, Sutton A, Rufat P, Charnaux N, Mansouri A, Moreau R, Carrié NG, Lemaire VG, Kontchou GN, Trinchet JC, Pessayre D, Beaugrand $M$. (2009). A variant in myeloperoxidase promoter hastens the emergence of hepatocellular carcinoma in patients with HCV-related cirrhosis. Hepatology , 56: 426-432. 
Table 1: Characterization of patients with $\mathrm{HCV}, \mathrm{HCC}$ according biochemical data in comparison with control subjects.

\begin{tabular}{|c|c|c|c|c|}
\hline Parameter & $\begin{array}{l}\text { Control } \\
\text { (Mean } \pm \text { S.D) } \\
\mathrm{N}=112\end{array}$ & $\begin{array}{c}\text { HCV } \\
(\mathrm{Mean} \pm \text { S.D) } \\
\mathrm{N}=\mathbf{2 4 3}\end{array}$ & $\begin{array}{l}\text { HCC } \\
(\text { Mean } \pm \text { S.D }) \\
\mathrm{N}=134 \\
\end{array}$ & P-Value \\
\hline TLC & $7.2 \pm 1.8$ & $6.5 \pm 9.3$ & $6.8 \pm 7.6$ & 0.713 \\
\hline HB(mmol/L) & $12.2 \pm 1.8$ & $13 \pm 1.9$ & $12.5 \pm 1.9$ & 0.006 \\
\hline PLT(1000/mm $\left.\mathbf{m}^{3}\right)$ & $273.3 \pm 66$ & $209.7 \pm 59.4$ & $157.7 \pm 91$ & 0.0001 \\
\hline $\operatorname{AST}(\mathbf{I U} / \mathbf{L})$ & $23.4 \pm 8$ & $54.7 \pm 32.2$ & $70.5 \pm 37.2$ & 0.0001 \\
\hline $\operatorname{ALT}(\mathbf{I U} / \mathbf{L})$ & $23.7 \pm 32.5$ & $63.4 \pm 43.9$ & $62.8 \pm 45.1$ & 0.0001 \\
\hline $\operatorname{Alb}(g / L)$ & $4.2 \pm 0.4$ & $4.1 \pm 0.6$ & $3.2 \pm 0.7$ & 0.0001 \\
\hline T.Bil(mg/dl) & $0.7 \pm 0.2$ & $0.9 \pm 0.6$ & $1.7 \pm 2.4$ & 0.0001 \\
\hline Creat(mg/dl) & $0.87 \pm 0.1$ & $0.9 \pm 0.2$ & $1.75 \pm 2.4$ & 0.0001 \\
\hline $\operatorname{AFP}(\mu \mathrm{g} / \mathrm{L})$ & $9.82 \pm 3.68$ & $60.4 \pm 304$ & $960.3 \pm 2300$ & 0.007 \\
\hline
\end{tabular}


Table 2:Allelic and genotypic frequencies of CAT gene polymorphisms in control and HCV patients .

*Allelic frequency

\begin{tabular}{|c|c|c|c|c|}
\hline CAT gene & $\begin{array}{l}\text { Control }(\%) \\
\left(n=112 / 224^{*}\right)\end{array}$ & $\begin{array}{l}\operatorname{HCV}(\%) \\
\left(n=243 / 486^{*}\right)\end{array}$ & OR $(95 \% \mathrm{CI})$ & P-value \\
\hline $\begin{array}{l}\text { Allele } \\
\text { C }\end{array}$ & $158(71 \%)$ & $275(57 \%)$ & $0.544(0.388-0.763)$ & 0.001 \\
\hline $\mathbf{T}$ & $66(29 \%)$ & $211(43 \%)$ & 1.83(1.309-2.577) & 0.001 \\
\hline \multicolumn{5}{|l|}{ Genotype } \\
\hline $\mathrm{CC}$ & $58(51.8)$ & 87(35.8) & $0.510(0.324-0.803)$ & 0.003 \\
\hline CT & $42(37.5)$ & $101(41.6)$ & $1.185(0.748-1.877)$ & 0.272 \\
\hline TT & $12(10.7)$ & $55(22.6)$ & $2.43(1.248-4.764)$ & 0.005 \\
\hline \multicolumn{5}{|c|}{ Combination } \\
\hline $\mathbf{C C}+\mathbf{C T}$ & $100(89.3)$ & $187(77)$ & $0.401(0.205-0.782)$ & 0.004 \\
\hline $\mathbf{C T}+\mathbf{T T}$ & $54(48.2)$ & $156(64.2)$ & $1.926(1.223-3.033)$ & 0.003 \\
\hline
\end{tabular}


Table 3: Allelic and genotypic frequencies of CAT gene polymorphisms in control and HCC patients .

*Allelic frequency

\begin{tabular}{|c|c|c|c|c|}
\hline CAT gene & $\begin{array}{l}\text { Control(\%) } \\
(n=112 / 224 *)\end{array}$ & $\begin{array}{l}\operatorname{HCC}(\%) \\
\left(n=134 / 268^{*}\right)\end{array}$ & OR(95\% CI) & P-value \\
\hline \multicolumn{5}{|l|}{ Allele } \\
\hline $\mathbf{C}$ & $158(71 \%)$ & $150(56 \%)$ & $0.531(0.364-0.772)$ & 0.001 \\
\hline $\mathbf{T}$ & $66(29 \%)$ & $118(44 \%)$ & $1.883(1.294-2.740)$ & 0.001 \\
\hline \multicolumn{5}{|l|}{ Genotype } \\
\hline $\mathbf{C C}$ & $58(51.8)$ & $47(35.1)$ & $0.503(0.301-0.840)$ & 0.006 \\
\hline CT & $42(37.5)$ & $56(41.8)$ & 1.197(0.716-2.001) & 0.290 \\
\hline TT & $12(10.7)$ & 31(23.1) & $2.508(1.220-5.158)$ & 0.008 \\
\hline \multicolumn{5}{|c|}{ Combination } \\
\hline $\mathrm{CC}+\mathrm{CT}$ & $100(89.3)$ & $103(76.9)$ & $0.399(0.194-0.820)$ & 0.008 \\
\hline $\mathbf{C T}+\mathbf{T T}$ & $54(48.2)$ & 87(64.9) & $1.988(1.190-3.321)$ & 0.006 \\
\hline
\end{tabular}




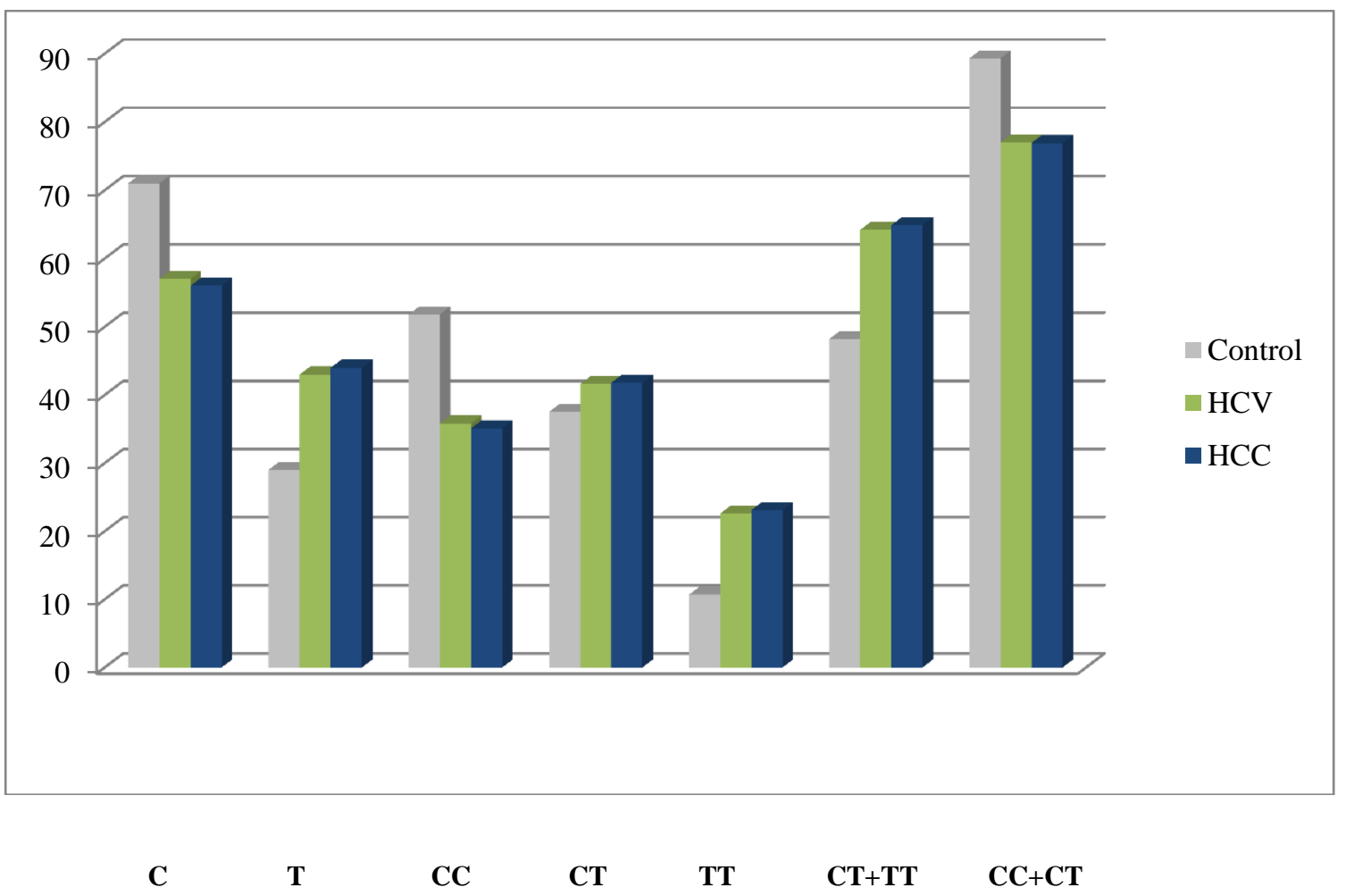

Fig 1:Percent of Allelic and genotypic frequencies of CAT gene polymorphisms in different groups. 


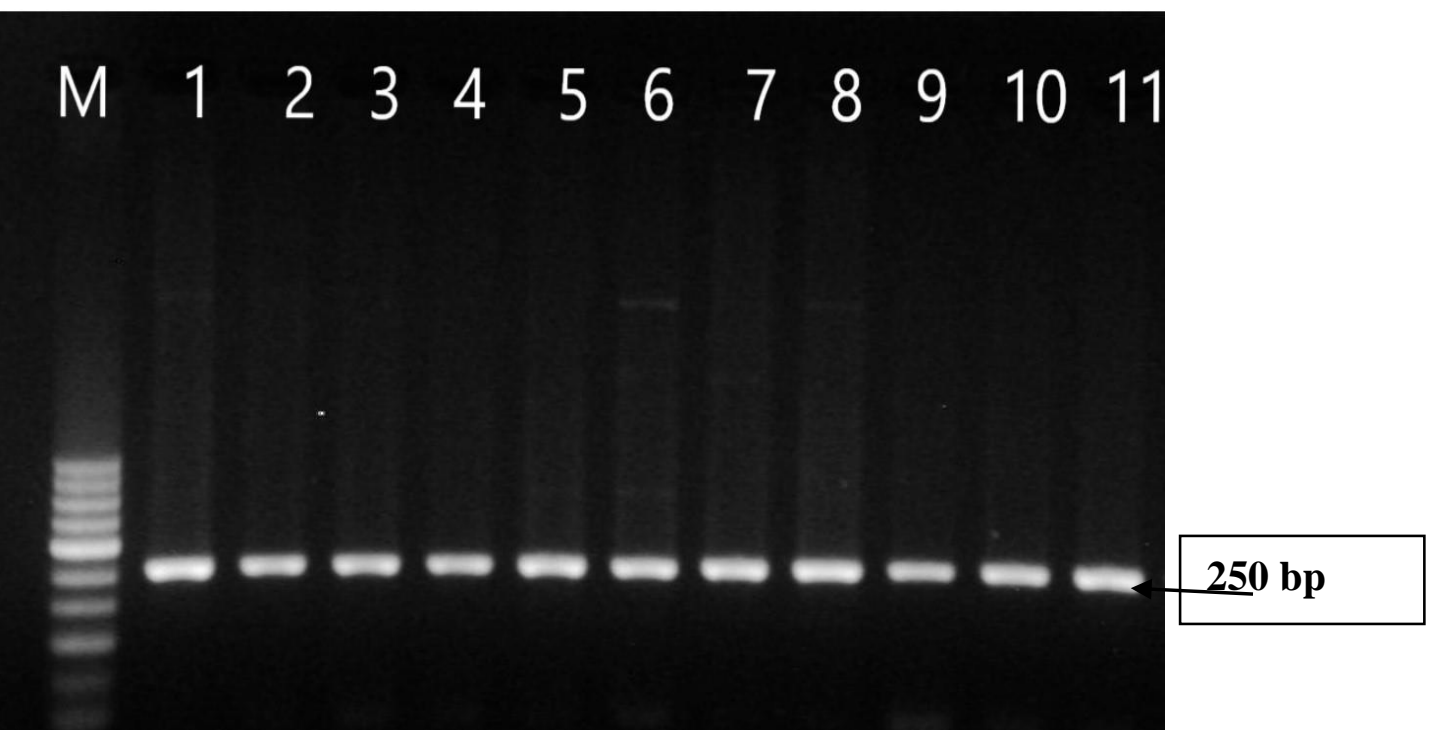

Fig.2. Agarose gel electrophoresis of Catalase gene (CAT) amplified by polymerase chain reaction. M: 50 bp DNA ladder,

Lanes 1-11: Amplified products for CAT gene

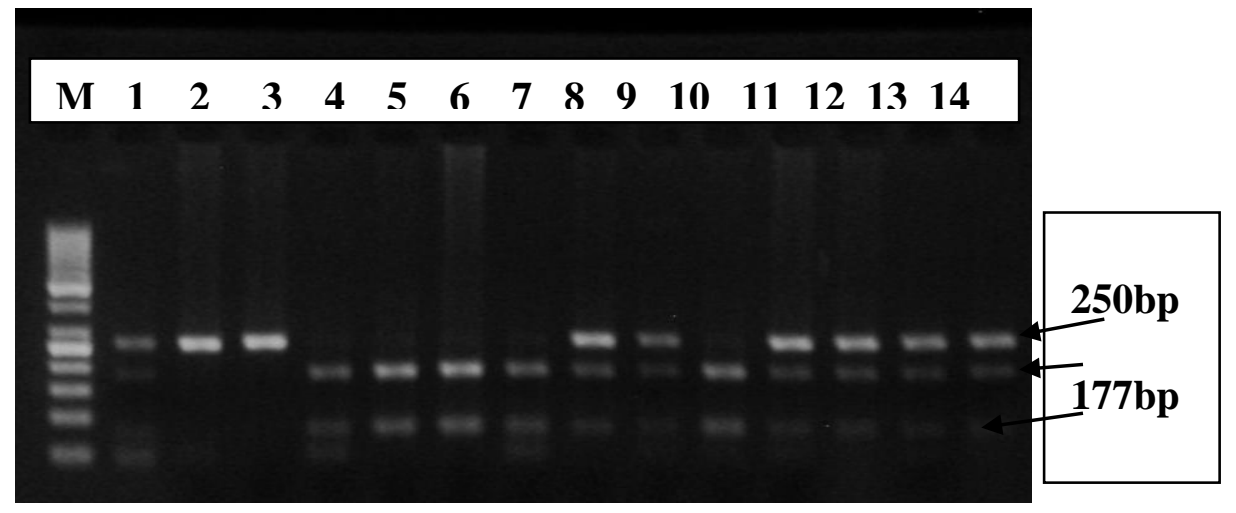

Fig.3. Electrophoresis band pattern of restriction fragment length polymorphism(RFLP) for (CAT) products digested by Hinf1

M: 50 bp DNA ladder,

Lanes $1,8,9,11,12,13$ and 14 : Heterozygous (CT).

Lanes 2 and 3: Wild (Homozygous) (CC).

Lanes 4, 5, 6 ,7 and 10: Homozygous mutated (TT). 